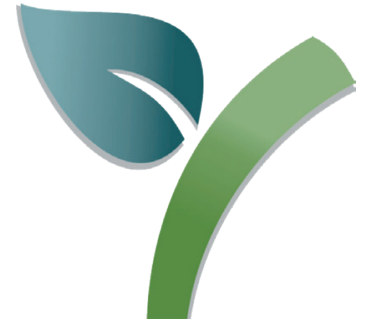

\title{
BIONEMATICIDES IN BRAZIL: AN EMERGING AND CHALLENGING MARKET
}

\author{
Andressa C. Z. Machado ${ }^{1}$
}

ECONOMICALLY

IMPORTANT

NEMATODES IN

BRAZIL

\begin{abstract}
Management of plant parasitic nematodes in Brazil is a challenge and bionematicides are an important tool in the Integrated Nematode Management in several crops. There are 47 commercial bionematicides with 11 microorganisms as active ingredient available for growers in Brazil; Bacillus spp. are the main biological control agents, but fungi are also important for nematode management. Bionematicides reached $82 \%$ of the total market of nematicides in 2019/2020 in Brazil and, in soybean, they represented $90 \%$ of the area treated with nematicides. Although, the use of bionematicides is considered an emerging market worldwide, some challenges involve the correct use and formulation of organisms with different modes of action, difficulties in laboratory culturing, and the existence of non-regulated bionematicides, which do not ensure the quality, the purity, and the efficiency in the nematode control under field conditions, leading to lack of control and discredit of this tool. Considering the Brazilian biodiversity richness, a universe of new macroand microorganisms can be explored, as well as the metabolites produced by these organisms as the active ingredient of bionematicides. Expectations of an increase in this market are optimistic and may materialize in light of the increasing demand for biological products in Brazil.
\end{abstract}

KEYWORDS: biological control, management, nematodes, biopesticides
In the last decades, nematodes had gained a prominent position in Brazilian agriculture among the main diseases that attack economically important crops, such as soybean, cotton, and coffee (MACHADO 2014). Information provided by the Brazilian Nematological Society realize that nematodes cause about US\$ 6.5 billion of yield losses in Brazilian agriculture annually; considering only the soybean crops, these losses correspond to US\$ 3 billion (considering 1 dollar = R\$ 5.3).

For some crops, as soybean, cotton, and maize, main nematode species are two root-knot nematodes, $M$. incognita and $M$. javanica (this second not parasitize cotton), the root-lesion nema- tode, Pratylenchus brachyurus, the soybean cyst nematode, Heterodera glycines (parasitize only soybean) and the reniform nematode, Rotylenchulus reniformis (MACHADO 2014). In coffee crops, M. exigua, $M$. incognita and $M$. paranaensis are the main nematode species causing extensive losses (OLIVEIRA \& ROSA 2018). Sugarcane is parasitized and damaged by $M$. incognita, $M$. javanica, P. brachyurus, and $P$. zeae (DINARDO-MIRANDA 2014), while $M$. enterolobii is a concern for fruit trees as guajava (Psidium guajava) and acerola (Malpighia emarginata) and vegetables (CARNEIRO 2003; PINHEIRO, 2017).

Symptoms involve in general the stunting of

${ }^{1}$ Instituto de Desenvolvimento Rural do Paraná - IAPAR/EMATER, Londrina, PR, 86047-902, Brazil. Corresponding author: Andressa C. Z. Machado. E-mail: andressa_machado@idr.pr.gov.br. 
plants, chlorosis and falling of leaves, flower abortion and lower yields. In the root system, the attack of root-knot nematodes is easy to recognize, since they incite the formation of enlarged nodes known as galls, but symptoms associated to the attack of Pratylenchus spp. and other nematode species are often unspecific and involve basically dark or necrotic lesions in roots, easily confounded with fungi or bacteria parasitism (FERRAZ \& BROWN 2016).

In addition to the significant damages and yield losses caused by different nematode species, difficulties in management of these pathogens lead to the great concern on plant-parasitic nematodes in Brazil. Management is done mainly by the use of resistant cultivars, the adoption of crop rotation with non-hosts, or with the application of chemical or biological nematicides (MACHADO 2016; MACHADO et al. 2016; ARITA et al. 2020; SILVA et al. 2020).

Unfortunately, few options of resistant cultivars are available for growers and some of them could not be recommended for the different agricultural areas in Brazil, due to the climatic restrictions. Crop rotation is also constrained by the high level of polyphagia observed in most of the nematode species, as $P$. brachyurus and $M$. incognita. In addition, non-hosts options include non-commercial plant species, as Crotalaria spectabilis, which reduce the chance of the grower adopting this management tool (SILVA et al. 2020).

Chemical and biological nematicides are good options for nematode management, especially when other management tools are not available or are difficult to be used. Despite the great importance of nematodes in Brazil, few chemical molecules are registered in the Brazilian Ministry of Agriculture, Livestock and Food Supply for the use in nematode infested fields (AGROFIT 2021). Until this moment, we have 12 active ingredients, which corresponds to 29 commercial products, registered for the control of nematodes. On the contrary, we have 11 biological agents and 47 commercial products recommended for nematode management (AGROFIT 2021).

\section{BIONEMATICIDE MARKET}

Biological control as an important tool in the Integrated Nematode Management is a reality in Brazil and worldwide nowadays. A global scale poll (https://www.agribusinessglobal.com/plant- health/biostimulants/state-of-the-industry-exclusive-survey-results-on-biological-products/) showed that the increasing demand for biological products are driving by consumers that require lower pesticide residues, followed by the environmental laws, favorable regulatory framework, and demand from farmers who are complying new purchasing strategies from large grocery retailers. These aspects are noticeable by the numbers presented in this survey: $58 \%$ of the companies interviewed say that they are integrating biological products into their portfolios and another $21 \%$ are looking to develop or offer biological products.

The global pesticide market registered an amount of US\$ 57.561 billion in 2018. The global biopesticide market represents a small portion of this, since in 2018 its value was around US\$ 3.14 billion, but the expected increase of this market will be around 14\% from 2019 to 2024 (AGROPAGES 2019). The Latin America biopesticide market represented US\$ 305.1 million in 2017; Brazil was the largest market, with US\$ 103.5 million in 2017, increasing to US\$ 200 million in 2019/2020 (CAMPOS 2021).

Brazilian biopesticide market was estimated in about US\$ 340 million in 2021, but projections are that biopesticides have the potential to increase $107 \%$ until 2030, reaching about US\$ 700 million (FRAGA 2021). This market is represented by $41 \%$ of insecticides, $24 \%$ of fungicides, and $35 \%$ of nematicides; soybean, sugarcane, and maize represent $75 \%$ of the biopesticide market in Brazil (FRAGA 2021). Specifically for soybean, more than 2.5 million hectares of this crop in Brazil were treated with bionematicides in the cropping season of 2018/2019 (DIAS 2020).

In relation to Brazilian nematicide market, bionematicides were used in $90 \%$ of the area cropped with soybean and treated with nematicides in 2019/2020; seed treatment represented $70 \%$ of the total bionematicide application in soybean. Together with other crop species, the use of bionematicides in Brazil reached $82 \%$ of the total market of nematicides in 2019/2020 (DIAS 2020). The main organisms used in commercial products in Brazil with nematicide action are bacteria, especially Bacillus spp., and fungi, as Purpureocillium (=Paecilomyces) lilacinum, Pochonia chlamydosporia, and Trichoderma spp. (AGROFIT 2021). 


\section{MAIN BIONEMATICIDES IN BRAZIL: ORGANISMS AND MODE OF ACTION}

Bacillus spp. In Brazil, Bacillus spp. are present in almost $60 \%$ of the commercial bionematicides (Table 1) (AGROFIT 2021). From 27 bionematicides containing Bacillus spp., B. amyloliquefaciens are present in 10 of them, B. subtilis in eight, as a single active ingredient, and three in mixture with $B$. licheniformis, followed by $B$. firmus (3), B. velezensis (2), and B. methylotrophicus (1).

These bacteria colonize the rhizosphere and develop associated to roots, stimulated by root exudates, where they form a physic-chemical barrier composed by bacterial cells and metabolites produced by them (HASHEM et al. 2019); this barrier avoids nematode penetration into roots (Figure 1). In addition, some isolates produce substances through their metabolism that are toxic to nema- todes, acting on different stages of the nematode development (KAVITHA et al. 2012; HU et al. 2017). The growth of the bacteria around the roots leads to an alteration in the composition of the root exudates, causing an interference in the recognizing process by the nematodes, since they are attracted in direction to roots by the chemical compounds of the root exudates from the host plant (HU et al. 2017).

Bacillus spp. are important plant growth promoters (plant growth promoting rhizobacteria). Through the endophytic colonization of the roots, they induce the production of growth regulators, specially phytohormones, which improve plant development (SANTOS et al. 2018). Besides, these bacteria can also act as resistance inducers (Figure 1), activating genes involved in the Systemic Induced Resistance (SIR) (CHOUDHARY \& JOHRI 2009).

Table 1. List of bionematicides registered for use in Brazil, according to Agrofit (2021).

\begin{tabular}{|c|c|c|c|c|}
\hline $\begin{array}{l}\text { Biological } \\
\text { agent }\end{array}$ & $\begin{array}{l}\text { Commercial } \\
\text { product }\end{array}$ & Concentration & Biological target & Company \\
\hline $\begin{array}{l}\text { Pasteuria nishi- } \\
\text { zawae }\end{array}$ & Clariva PN & $\begin{array}{c}1 \times 10^{10} \text { endospores } \\
/ \mathrm{mL}\end{array}$ & Heterodera glycines & $\begin{array}{c}\text { Syngenta Proteção de Cultivos } \\
\text { Ltda. }\end{array}$ \\
\hline $\begin{array}{l}\text { Pasteuria nishi- } \\
\text { zawae }\end{array}$ & Clariva PN BR & $\begin{array}{c}1 \times 10^{10} \text { endospores } \\
/ \mathrm{mL}\end{array}$ & Heterodera glycines & $\begin{array}{c}\text { Syngenta Proteção de Cultivos } \\
\text { Ltda. }\end{array}$ \\
\hline Bacillus firmus & Andril Prime & $4 \times 10^{9} \mathrm{CFU} / \mathrm{g}$ & $\begin{array}{l}\text { Pratylenchus brachyurus, } \\
\text { Meloidogyne javanica }\end{array}$ & BASF S.A. \\
\hline Bacillus firmus & Oleaje Prime & $4 \times 10^{9} \mathrm{CFU} / \mathrm{g}$ & $\begin{array}{l}\text { Meloidogyne javanica, } \\
\text { Pratylenchus brachyurus }\end{array}$ & BASF S.A. \\
\hline Bacillus firmus & Votivo Prime & $4 \times 10^{9} \mathrm{CFU} / \mathrm{g}$ & $\begin{array}{l}\text { Meloidogyne javanica, } \\
\text { Pratylenchus brachyurus }\end{array}$ & BASF S.A. \\
\hline $\begin{array}{l}\text { Bacillus amylo- } \\
\text { liquefaciens }\end{array}$ & Aveo EZ & $6.1 \times 10^{10} \mathrm{CFU} / \mathrm{mL}$ & $\begin{array}{c}\text { Pratylenchus brachyurus, } \\
\text { Meloidogyne incognita } \\
\text { Heterodera glycines }\end{array}$ & $\begin{array}{l}\text { Sumitomo Chemical do Brasil } \\
\text { Representações Ltda }\end{array}$ \\
\hline $\begin{array}{l}\text { Bacillus amylo- } \\
\text { liquefaciens }\end{array}$ & Lumialza & $6.1 \times 10^{10} \mathrm{CFU} / \mathrm{mL}$ & $\begin{array}{l}\text { Heterodera glycines, Meloidogyne } \\
\text { incognita, Pratylenchus brachyurus }\end{array}$ & $\begin{array}{l}\text { Sumitomo Chemical do Brasil } \\
\text { Representações Ltda }\end{array}$ \\
\hline $\begin{array}{l}\text { Bacillus amylo- } \\
\text { liquefaciens }\end{array}$ & Trunemco & $\begin{array}{c}1 \times 10^{10} \text { endospores } \\
/ \mathrm{mL}\end{array}$ & $\begin{array}{c}\text { Meloidogyne incognita, Meloidogyne } \\
\text { javanica, Pratylenchus brachyurus, } \\
\text { Rotylenchulus reniformis }\end{array}$ & $\begin{array}{l}\text { Sumitomo Chemical do Brasil } \\
\text { Representações Ltda }\end{array}$ \\
\hline Bacillus subtilis & Baci-Attack & $1 \times 10^{8} \mathrm{CFU} / \mathrm{mL}$ & $\begin{array}{l}\text { Meloidogyne incognita, } \\
\text { Meloidogyne javanica }\end{array}$ & $\begin{array}{c}\text { Vittia Fertilizantes e Biológicos } \\
\text { S.A. }\end{array}$ \\
\hline Bacillus subtilis & Baci-Guard & $4 \times 10^{8} \mathrm{CFU} / \mathrm{mL}$ & $\begin{array}{l}\text { Meloidogyne incognita, } \\
\text { Meloidogyne javanica }\end{array}$ & $\begin{array}{c}\text { Vittia Fertilizantes e Biológicos } \\
\text { S.A. }\end{array}$ \\
\hline Bacillus subtilis & Biobaci & $1 \times 10^{8} \mathrm{CFU} / \mathrm{mL}$ & $\begin{array}{c}\text { Meloidogyne javanica, Meloidogyne } \\
\text { incognita, Meloidogyne exigua, Me- } \\
\text { loidogyne paranaensis, } \\
\text { Pratylenchus zeae }\end{array}$ & $\begin{array}{c}\text { Vittia Fertilizantes e Biológicos } \\
\text { S.A. }\end{array}$ \\
\hline $\begin{array}{l}\text { Bacillus amylo- } \\
\text { liquefaciens }\end{array}$ & Nema-Attack & $3 \times 10^{9} \mathrm{CFU} / \mathrm{mL}$ & Meloidogyne incognita & $\begin{array}{c}\text { Vittia Fertilizantes e Biológicos } \\
\text { S.A. }\end{array}$ \\
\hline $\begin{array}{l}\text { Bacillus amylo- } \\
\text { liquefaciens }\end{array}$ & Nema-Guard & $3 \times 10^{9} \mathrm{CFU} / \mathrm{mL}$ & Meloidogyne incognita & $\begin{array}{c}\text { Vittia Fertilizantes e Biológicos } \\
\text { S.A. }\end{array}$ \\
\hline
\end{tabular}


Table 1. Continued

\begin{tabular}{|c|c|c|c|c|}
\hline $\begin{array}{c}\text { Biological } \\
\text { agent }\end{array}$ & $\begin{array}{c}\text { Commercial } \\
\text { product }\end{array}$ & Concentration & Biological target & Company \\
\hline $\begin{array}{l}\text { Bacillus amylo- } \\
\text { liquefaciens }\end{array}$ & No-Nema & $3 \times 10^{9} \mathrm{CFU} / \mathrm{g}$ & $\begin{array}{c}\text { Heterodera glycines, } \\
\text { Meloidogyne incognita, Meloidogyne } \\
\text { javanica, Pratylenchus brachyurus }\end{array}$ & $\begin{array}{l}\text { Vittia Fertilizantes e Biológicos } \\
\text { S.A. }\end{array}$ \\
\hline $\begin{array}{l}\text { Bacillus } \\
\text { velezensis }\end{array}$ & Bionema & $\begin{array}{l}3.5 \times 10^{11} \text { endo- } \\
\text { spores / L }\end{array}$ & Meloidogyne incognita & $\begin{array}{c}\text { Biotrop Soluções Biológicas e } \\
\text { Participações Ltda }\end{array}$ \\
\hline Bacillus subtilis & Furatrop & $1.9 \times 10^{12} \mathrm{CFU} / \mathrm{L}$ & Meloidogyne javanica & $\begin{array}{c}\text { Biotrop Soluções Biológicas e } \\
\text { Participações Ltda }\end{array}$ \\
\hline Bacillus subtilis & Nematrop & $1.9 \times 10^{12} \mathrm{CFU} / \mathrm{L}$ & Meloidogyne javanica & $\begin{array}{c}\text { Biotrop Soluções Biológicas e } \\
\text { Participações Ltda }\end{array}$ \\
\hline Bacillus subtilis & Promobio & $1.9 \times 10^{12} \mathrm{CFU} / \mathrm{L}$ & Meloidogyne javanica & $\begin{array}{l}\text { Biotrop Soluções Biológicas e } \\
\text { Participações Ltda }\end{array}$ \\
\hline Bacillus subtilis & Paladyo & $1.9 \times 10^{12} \mathrm{CFU} / \mathrm{L}$ & Meloidogyne javanica & $\begin{array}{c}\text { Biotrop Soluções Biológicas e } \\
\text { Participações Ltda }\end{array}$ \\
\hline $\begin{array}{l}\text { Bacillus } \\
\text { velezensis }\end{array}$ & Rudder & $\begin{array}{l}3.5 \times 10^{11} \text { endo- } \\
\text { spores / L }\end{array}$ & Meloidogyne incognita & $\begin{array}{c}\text { Biotrop Soluções Biológicas e } \\
\text { Participações Ltda }\end{array}$ \\
\hline $\begin{array}{l}\text { Bacillus amylo- } \\
\text { liquefaciens }\end{array}$ & Boneville & $1 \times 10^{10} \mathrm{CFU} / \mathrm{g}$ & $\begin{array}{c}\text { Meloidogyne incognita, Meloidogyne } \\
\text { javanica, Pratylenchus brachyurus }\end{array}$ & Koppert do Brasil Holding Ltda \\
\hline $\begin{array}{l}\text { Bacillus amylo- } \\
\text { liquefaciens }\end{array}$ & Chevelle & $1 \times 10^{10} \mathrm{CFU} / \mathrm{g}$ & $\begin{array}{c}\text { Meloidogyne incognita, Meloidogyne } \\
\text { javanica, Pratylenchus brachyurus }\end{array}$ & Koppert do Brasil Holding Ltda \\
\hline $\begin{array}{l}\text { Bacillus amylo- } \\
\text { liquefaciens }\end{array}$ & Veraneio & $1 \times 10^{10} \mathrm{CFU} / \mathrm{g}$ & $\begin{array}{c}\text { Meloidogyne incognita, Meloidogyne } \\
\text { javanica, Pratylenchus brachyurus }\end{array}$ & Koppert do Brasil Holding Ltda \\
\hline $\begin{array}{l}\text { Bacillus amylo- } \\
\text { liquefaciens }\end{array}$ & $\begin{array}{c}\text { Nemacontrol / } \\
\text { Nemacontrol } \\
\text { Super }\end{array}$ & $\begin{array}{l}5 \times 10^{9} \mathrm{CFU} / \mathrm{mL} \\
1 \times 10^{10} \mathrm{CFU} / \mathrm{mL}\end{array}$ & $\begin{array}{c}\text { Pratylenchus brachyurus / } \\
\text { Pratylenchus brachyurus } \\
\text { Meloidogyne javanica }\end{array}$ & $\begin{array}{c}\text { Simbiose Indústria e Comércio } \\
\text { de Fertilizantes e Insumos Mi- } \\
\text { crobiológicos Ltda }\end{array}$ \\
\hline $\begin{array}{l}\text { Bacillus methy- } \\
\text { lotrophicus }\end{array}$ & $\begin{array}{l}\text { Onix / Onix } \\
\text { OG* }\end{array}$ & $1 \times 10^{9} \mathrm{CFU} / \mathrm{g}$ & $\begin{array}{l}\text { Meloidogyne javanica, } \\
\text { Pratylenchus brachyurus }\end{array}$ & $\begin{array}{c}\text { Lallemand Soluções Agrobi- } \\
\text { ológicas Ltda }\end{array}$ \\
\hline Bacillus subtilis & $\begin{array}{c}\text { Rizos / Rizos } \\
\text { OG* }\end{array}$ & $3 \times 10^{9} \mathrm{CFU} / \mathrm{mL}$ & $\begin{array}{l}\text { Meloidogyne javanica, } \\
\text { Pratylenchus brachyurus }\end{array}$ & $\begin{array}{l}\text { Lallemand Soluções Agrobi- } \\
\text { ológicas Ltda }\end{array}$ \\
\hline $\begin{array}{l}\text { Bacillus licheni- } \\
\text { formis + Bacil- } \\
\text { lus subtilis }\end{array}$ & Presence & $\begin{array}{c}1 \times 10^{11}+1 \times 10^{11} \\
\mathrm{CFU} / \mathrm{g}\end{array}$ & $\begin{array}{l}\text { Meloidogyne incognita, } \\
\text { Pratylenchus brachyurus }\end{array}$ & FMC Química do Brasil Ltda \\
\hline $\begin{array}{l}\text { Bacillus licheni- } \\
\text { formis + Bacil- } \\
\quad \text { lus subtilis }\end{array}$ & Quartzo & $\begin{array}{c}1 \times 10^{11}+1 \times 10^{11} \\
\mathrm{CFU} / \mathrm{g}\end{array}$ & $\begin{array}{c}\text { Meloidogyne incognita, Meloidogyne } \\
\text { javanica, Meloidogyne graminicola, } \\
\text { Meloidogyne exigua, Pratylenchus } \\
\text { brachyurus, Radopholus similis }\end{array}$ & FMC Química do Brasil Ltda \\
\hline $\begin{array}{l}\text { Bacillus li- } \\
\text { cheniformis }+ \\
\text { Bacillus subtilis } \\
+ \text { Paecilomyces } \\
\quad \text { lilacinus }\end{array}$ & $\begin{array}{l}\text { Profix / Pro- } \\
\text { fix-A / Profix-B } \\
\text { / Profix-C }\end{array}$ & $\begin{array}{l}1 \times 10^{10}+1 \times 10^{10}+ \\
1 \times 10^{9} \mathrm{CFU} / \mathrm{g}\end{array}$ & $\begin{array}{l}\text { Meloidogyne incognita, } \\
\text { Pratylenchus brachyurus }\end{array}$ & $\begin{array}{l}\text { Agrivalle Brasil Indústria e Co- } \\
\text { mércio de Produtos Agrícolas } \\
\text { S.A. }\end{array}$ \\
\hline $\begin{array}{l}\text { Paecilomyces } \\
\text { lilacinus }\end{array}$ & ATIALY & $1 \times 10^{5} \mathrm{CFU} / \mathrm{g}$ & Meloidogyne incognita & $\begin{array}{c}\text { Agrobiológica Sustentabilidade } \\
\text { S.A. }\end{array}$ \\
\hline $\begin{array}{l}\text { Paecilomyces } \\
\text { lilacinus }\end{array}$ & BN40.001/19* & $7.5 \times 10^{9} \mathrm{CFU} / \mathrm{g}$ & Meloidogyne incognita & Ballagro Agro Tecnologia Ltda \\
\hline $\begin{array}{l}\text { Paecilomyces } \\
\text { lilacinus }\end{array}$ & Nemat & $7.5 \times 10^{9} \mathrm{CFU} / \mathrm{g}$ & $\begin{array}{c}\text { Meloidogyne incognita, Meloidogyne } \\
\text { javanica, Pratylenchus brachyurus }\end{array}$ & Ballagro Agro Tecnologia Ltda \\
\hline $\begin{array}{l}\text { Paecilomyces } \\
\text { lilacinus }\end{array}$ & Nettus* & $7.5 \times 10^{9} \mathrm{CFU} / \mathrm{g}$ & Meloidogyne incognita & Ballagro Agro Tecnologia Ltda \\
\hline $\begin{array}{l}\text { Paecilomyces } \\
\text { lilacinus }\end{array}$ & $\begin{array}{l}\text { Purpureonyd } \\
\text { FR } 25\end{array}$ & $6.5 \times 10^{7} \mathrm{CFU} / \mathrm{g}$ & Meloidogyne incognita & TZ Biotech Ltda \\
\hline $\begin{array}{c}\text { Pochonia } \\
\text { chlamydosporia }\end{array}$ & Rizotec & $\begin{array}{c}5.2 \times 10^{7} \text { chlamydo- } \\
\text { spores / g }\end{array}$ & Meloidogyne javanica & Rizoflora Biotecnologia Ltda \\
\hline
\end{tabular}


Table 1. Continued

\begin{tabular}{|c|c|c|c|c|}
\hline $\begin{array}{c}\text { Biological } \\
\text { agent }\end{array}$ & $\begin{array}{l}\text { Commercial } \\
\text { product }\end{array}$ & Concentration & Biological target & Company \\
\hline $\begin{array}{c}\text { Pochonia } \\
\text { chlamydosporia }\end{array}$ & $\begin{array}{l}\text { PC-ATTACK / } \\
\text { PC-GUARD }\end{array}$ & $1 \times 10^{6} \mathrm{CFU} / \mathrm{mL}$ & Meloidogyne javanica & $\begin{array}{c}\text { Vittia Fertilizantes e Biológicos } \\
\text { S.A. }\end{array}$ \\
\hline $\begin{array}{c}\text { Pochonia } \\
\text { chlamydosporia }\end{array}$ & RIZO-TURBO & $1 \times 10^{6} \mathrm{CFU} / \mathrm{mL}$ & Meloidogyne javanica & $\begin{array}{c}\text { Vittia Fertilizantes e Biológicos } \\
\text { S.A. }\end{array}$ \\
\hline $\begin{array}{l}\text { Trichoderma } \\
\text { harzianum }\end{array}$ & $\begin{array}{l}\text { Trianum DS / } \\
\text { Trianum WG }\end{array}$ & $1 \times 10^{8} \mathrm{CFU} / \mathrm{g}$ & Pratylenchus brachyurus & Koppert do Brasil Holding Ltda \\
\hline $\begin{array}{l}\text { Trichoderma } \\
\text { harzianum }\end{array}$ & $\begin{array}{l}\text { Trichodermil } \\
\text { SC 1306/ Trich- } \\
\text { odermil Super } \\
\text { SC } 1306\end{array}$ & $2 \times 10^{9}$ conidia $/ \mathrm{mL}$ & Pratylenchus zeae & Koppert do Brasil Holding Ltda \\
\hline $\begin{array}{l}\text { Trichoderma } \\
\text { harzianum }\end{array}$ & $\begin{array}{l}\text { TRICHO-TUR- } \\
\text { BO }\end{array}$ & $\begin{array}{c}1 \times 10^{10} \text { conidia / } \\
\mathrm{mL}\end{array}$ & Pratylenchus brachyurus & $\begin{array}{c}\text { Vittia Fertilizantes e Biológicos } \\
\text { S.A. }\end{array}$ \\
\hline
\end{tabular}

*Bionematicide with approved use on organic agriculture.

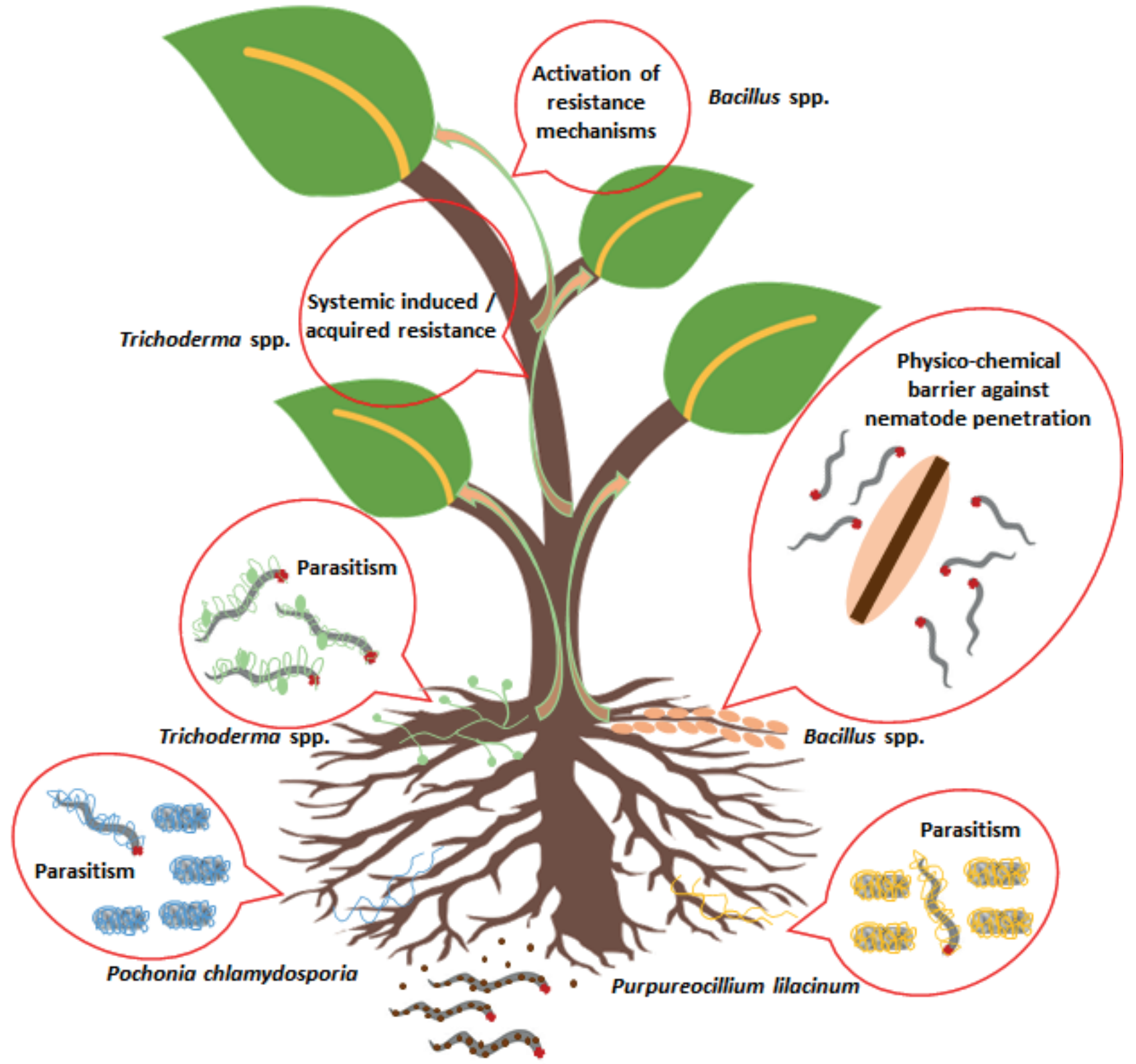

Pasteuria spp.

Parasitism

Figure 1. Main modes of action of different biological control agents on nematodes. 
Pasteuria nishizawae. Only two bionematicides are registered in Brazil with P. nizhizawae as the active ingredient (Table 1) (AGROFIT 2021). This species is recommended for the control of $\mathrm{H}$. glycines, since the bacteria in this genus are characterized as obligatory parasites of nematodes with high specificity. For instance, $P$. nishizawae is a parasite of $H$. glycines, $P$. penetrans of Meloidogyne spp., and $P$. thornei of Pratylenchus spp. (PRESTON et al. 2003); no bionematicide is available with this last two species in its composition. This specificity could be considered as an advantage in comparison to non-selective chemical nematicides that interfere on the micro and meso fauna present in the soil ecosystem, but also as a challenge to use Pasteuria spp. as a biological control agent (ORR et al. 2020).

The formulation of the two bionematicides is composed by bacterial spores, a resistant structure that allows the survival of this microorganism under unfavorable conditions. These spores adhere to the cuticle of nematodes during its moving in the soil (Figure 1), remaining dormant until the nematode initiates the parasitism. So, a germinative tube penetrates the cuticle and grows into the nematode body, where the bacteria extract the nutrients necessary to its development (DAVIES et al. 1988). Colonizing the interior of the nematode, Pasteuria spp. compromise the nematode reproduction, since the reproductive system can be completely damaged by the bacteria (DAVIES et al. 2011). A number of approximately 40 bound endospores that effectively encumber a nematode juvenile prevents root infection (STIRLING 1984), but more than 100 endospores may bind to the cuticle of the nematode, suppressing the infection of plants by this pathogen (PRESTON et al. 2003).

The spores used in the formulation increase the shelf life of the bionematicides and allow the survival of the bacteria between the cropping seasons. However, it is difficult to develop protocols for Pasteuria spp. propagation outside of the nematode host that allow the production of endospores for field application. Besides, as spores are immobile and Pasteuria spp. do not have saprophytic abilities, the efficiency of bionematicides formulated with these microorganisms is dependent on the presence of the mobile forms of the nematode, the juveniles, that are the main stage used by these bacteria to initiate its parasitism (PRESTON et al. 2003).
Trichoderma spp. There are four bionematicides with $T$. harzianum as the active ingredient registered for nematode control in Brazil (Table 1). Pratylenchus brachyurus and $P$. zeae are the biological targets for all these bionematicides (AGROFIT 2021), and this can be attributed to the high capacity of Trichoderma spp. to induce resistance in plants. The colonization of roots by Trichoderma spp. induces physiological changes in plants that lead to the activation of defense mechanisms (Figure 1). So, plants try to stop the endophytic colonization of Trichoderma spp. through the reinforcement of the cell walls and through the accumulation of antimicrobial compounds and reactive oxygen species (MARTÍNEZ-MEDINA et al. 2013). After this initial defense, the expression of defense genes returns to the pre-infectional levels, allowing the development of the fungus as an avirulent endosymbiont (MASUNAKA et al. 2011).

After the attack of a biotrophic pathogen, as the sedentary nematodes, the plant local reaction is the programed cell death, called hypersensitive reaction, followed by a systemic response that prevents the infection of healthy tissues not infected by the nematode; this response is known as Systemic Acquired Resistance (SAR) and is mediated by salicylic acid (MARTíNEZ-MEDINA et al. 2017). For herbivores, necrotrophic pathogens, and migratory endoparasitic nematodes, the plant reaction is called Systemic Induced Resistance (SIR) and is regulated by jasmonic acid and ethylene (LEONETTI et al. 2014). During the feeding, Pratylenchus spp. induce cytoplasmic streaming and rarely cell death, but their migration into roots induces cell death along the migration path (MATHEW \& OPPERMAN 2020).

The resistance induced by Trichoderma spp. can generate a priming effect, which allow that the resistance mechanisms are activated more quickly and effectively when the plant is challenged by different pathogens, as a "collection" of different stresses (PASCHOLATI et al. 2019). The priming effect generated by Trichoderma spp. was reported to be transgenerational, i.e., when parental plants are pre-conditioned, plants from the next generation showed the same level of resistance to nematodes without fitness costs (MEDEIROS et al. 2017).

In addition to this effect, Trichoderma spp. can also produce toxic compounds to nematodes that reduce hatching and cause mortality of juve- 
niles in in vitro studies, can prevent nematode penetration by the colonization of roots that leads to competition for feeding sites (VARGAS et al., 2009), and can parasitize nematode eggs and juveniles (ZHANG et al., 2017).

Purpureocillim lilacinum. This is an opportunistic fungus that parasites eggs, juveniles, and adults of different nematode species (Figure 1). There are six bionematicides available in Brazil with this fungus in their composition, five of them formulated exclusively with $P$. lilacinum and one formulated in mixture with Bacillus spp. (Table 1). The main biological targets are Meloidogyne spp. (AGROFIT 2021) and several studies showed that the efficiency of control conferred by $P$. lilacinum on sedentary nematodes can reach 70\% (DALLEMOLE-GIARETTA et al. 2012). The chitinolytic ability of this fungus is responsible to the success in its parasitism, which initiates with the infection of eggs and sedentary females by the fungal hyphae that secrete extracellular enzymes, as chitinases and proteases, degrading the eggshells and the cuticle of the female body. Hyphae absorb the cellular content from eggs and sedentary females, acquiring essential nutrients for their development and reproduction (MORTON et al. 2004). The egg masses deposited by Meloidogyne spp. sedentary females can be completely parasitized by $P$. lilacinum, which leads to alterations in the embryogenic development of the juveniles inside eggs and to unhatched eggs (AHMED \& MONJIL 2019).

Purpureocillium lilacinum also produces toxic substances to migratory nematodes, as $P$. brachyurus. Although not completely characterized, these substances immobilize the juveniles and prevent their penetration into roots (KHAN et al. 2006). This fungus also induces resistance in plants, through salicylic acid- or jasmonic acid-triggered responses (GHAHREMANI et al. 2019), as detailed for Trichoderma spp.

Pochonia chlamydosporia. Only three bionematicides are available in Brazil composed by $P$. chlamydosporia (Table 1). The mode of action of this fungus (Figure 1) is quite similar to that described to P. lilacinum (ESCUDERO et al. 2016; PODESTÁ et al. 2016) and it is also a saprophytic species in the absence of plants and nematode hosts (MANZANIL-
LA-LÓPEZ et al. 2013). Its endophytic behavior in some plant species can also result in activation of plant defense mechanisms against soil-borne pathogens, as nematodes (MACIÁ-VICENTE et al. 2009).

The best formulations should use chlamydospores of $P$. chlamydosporia, since conidia and hyphal fragments are sensitive and show lower survival rates in comparison to chlamydospores, that are resistance structures specialized for survival (DALLEMOLE-GIARETTA et al. 2011). These resistance structures have food reserves to allow the establishment of the fungus without the addition of supplementary energy sources (MAUCHLINE et al. 2002), on the contrary of conidia and hyphal fragments, that can get into fungistasis if no supplementary energy source is provided (KERRY et al. 1993). In this regard, to improve the performance of $P$. chlamydosporia in relation to the control of $M$. javanica, Escudero et al. (2016) associated chitosan as a supplementary energy source to fungi suspension containing hyphal fragments and obtained an increase in the infectivity and efficacy of the fungus in the suppression of nematode populations, in in vitro experiments.

\section{CHALLENGES IN THE DEVELOPMENT OF BIOLOGI- CAL BIOPESTICIDES}

In Brazil, the development of a biological product takes around five years, and the cost estimated is about US\$ 7 million. The process is initiated with the research of novel biological agents, a step that involves the identification of these organisms, the establishment of protocols for fermentation process, previous in vitro evaluations against different biological targets, and the identification of metabolites generated by the organism during its fermentation. The next step is the production and formulation of the product, which involves the enhancement of the multiplication process of the organism, the development of a quality control protocol, and the evaluation of performance and stability of the formulation (MARRONE 2019).

After this, the formulation follows to field evaluations, when studies are conducted under greenhouse and field conditions to determine the efficacy in large scale and, if necessary, to indicate formulation adjustments. The final step analyzes the security of the product and finalize with the approval and register of the new product; for this, com- 
panies must generate dossiers containing studies that ensure the security of the formulation, that are submitted to the governmental regulators (in Brazil: Brazilian Ministry of Agriculture, Livestock and Food Supply (MAPA), Brazilian Health Regulatory Agency (ANVISA), and Brazilian Institute of Environment and Renewable Natural Resources (IBAMA)), that can give the permission or deny the registration of the new biopesticide (MARRONE 2019).

Although, all these steps need to be transposed by companies to register a new bionematicide. Brazil has a modern regulatory apparatus, in agreement with international guidelines and regulations. For example, we have specific pioneering legislation on the evaluation of microbiological products for phytosanitary use (RDCs 194 and 195/2002 - ANVISA; IN 95/2020 - MAPA). According to the National Bioinput Program (PNB), there is a clear public policy for financing production and use of biological inputs in Brazil, offering credit lines and financing of up $30 \%$ of the capital costs invested in the construction of biofactories (GAZZONI 2021).

However, although the government incentives and the fact that several new bionematicides are available for growers in Brazil, some challenges need to be transposed and new alternatives should be evaluated. The first challenge to be addressed is the training and capacitation of distributors and growers in the correct use of the different biological control agents. Companies in Brazil are investing in studies to guarantee more precise positioning of the bionematicides in each crop and under the different Brazilian edaphoclimatic conditions. CropLife Brasil (CLB) provided a website (https://croplifebrasil.org/) with general information on technical aspects of the biological control and all the regulatory processes involved in the registration of biological products in Brazil, that helps technicians, companies, and growers to develop and use biological control agents.

Besides, the understanding on the mode of action of the different biological control agents (Figure 1), ensure that they will be used for the specific target and under the best formulation and application technology to allow maximum efficiency. The inclusion of bionematicides in the precision agriculture programs could also enhance the efficiency of the biological control agent (FARIA JUNIOR 2017). Even when the biological control agent is applied correctly in the site where the biological target is present, the product can be lost by drift or run-off; so, formulations should contain additives, as surfactants or adjuvants to ensure the efficacy of control. Nevertheless, some additives can be bioincompatible and this is one of the reasons why several products with living organisms do not contain these substances (SKRABANIA 2019).

Another challenge is the high cost of investment required for research and development of formulations that ensure the survival of the biological control agent under unfavorable conditions of storage and application in the field, as well as that ensure compatibility under mixture with other agricultural products. In addition, the stability of the formulation to degradation by UV light can also be challenging. It is important because the majority of crops in Brazil are cultivated under the conventional tillage, which represents $45 \%$ of the soil cultivation system (IBGE 2017) and involves soil disturbance; the soil is exposed until the establishment of the next crop and sowing is often done in dry soil conditions, reducing the chances of a biological control agent to establish itself properly. One of the ways to protect the organism in the formulation is by using microencapsulation techniques that improve stability and can be used to control the rate of release of the organism (BULLOCK 2019).

Moisture and temperature can be critical factors influencing the survival of fungal and bacterial agents. Under dry conditions, the metabolism of some organisms is reduced to allow their survival in a dormant state, as the survival specialized structures of some fungi, as the chlamydospores produced by P. chlamydosporia (MASSOLA JÚNIOR 2018). Another strategy for survival is the sporulation of some bacteria, as Bacillus spp., in which the bacterial genome is sequestered in the spore (or endospore), a survival structure, until the environmental conditions return to adequate levels for germination of this spore (McKENNEY et al. 2013). Therefore, if environmental conditions are unfavorable to biological control agents, they can go into dormancy and nematodes present in the soil will penetrate roots and develop normally until the organisms return to the normal activity, leading to lower and/or inconsistent efficacy compared to chemical nematicides, readily available in the soil.

In addition, for bionematicides formulated with bacterial endospores, as those composed by 
Bacillus spp. and Pasteuria spp., the difficulties in inducing the production of endospores in in vitro cultures in large scale for field application is a challenge. Sequencing of the genomes of these bacteria could help in the identification of their metabolic capabilities and limitations to optimize the in vitro multiplication. Besides, bioinformatic tools could help in the selection of isolates of parasitic bacteria more aggressive in the attachment, infection, and germination in different species of plant-parasitic nematodes (PRESTON et al. 2003).

Another important challenge to the biological control market of nematodes in Brazil is the existence of non-regulated bionematicides, without registration in the Brazilian Ministry of Agriculture, Livestock and Food Supply. These bionematicides do not ensure the quality, the purity, and the efficiency on the nematode control under field conditions, leading to lack of control and discredit of this tool. Moreover, the on-farm technology, when the grower produces the biological control agent in his farm with low or no control of inoculum and fermentation process, can result in the contamination and reproduction of other microorganisms that can be pathogenic to the crops, harmful to the environment, and also to the applicator. Brazilian government must legislate laws to regularize this situation through strict quality control rules to ensure the credibility of this management tool (FARIA JUNIOR 2017).

\section{CHALLENGES IN THE USE OF BIONEMATICIDES IN TROPICAL AND SUBTROPICAL CLIMATES}

Tropical and subtropical climates represent an additional challenge for the use of biological control agents, especially due to the high temperatures which often are inadequate to the survival of the organism. Under these climates, several nematode species can be present together in the same field and this is limiting when species-specific organisms are used in the biological control, as Pasteuria spp. Warm climates also allow nematode population densities to increase significantly during the cropping season (GRECO \& DI VITO 2009). In the Brazilian Cerrado region, temperatures do not vary greatly between seasons and crops are subsequently cropped in the field, allowing nematodes to reproduce continuously in the presence of the host and favorable soil moisture content and optimal temperatures for their development.
In addition to the inherent aspects of the commercial bionematicides, as formulation, which could impact directly in the shelf life of these products, some strategies can be adopted by growers to guarantee better results when using bionematicides in tropical and subtropical climates. In Brazil, bionematicides are applied mainly through seed treatment and, to a lesser extent, in furrow and via drench (MACHADO et al. 2016). In crops like cotton, bacteria are the preferred agents to be used as seed treatment, especially those from the genus Bacillus, while fungi are applied in furrow (MACHADO 2021).

This strategy could be a good option considering that cotton monoculture during the summer season is the main production system in Brazil (LAMAS et al. 2016), with intense soil disturbance that could interfere in the survival of biological organisms. The use of spore-forming bacteria as seed treatment in this situation could increase the efficiency of control, since endospores are survival structures which allow bacteria to survive under unfavorable conditions. On the other hand, in the in-furrow application in fields where cover crops are used in mid-season, fungi could also be applied at sowing, or in the debris following desiccation of the cover crop prior to cotton or another main crop, when soil moisture and temperatures are regulated by the mulch, allowing the establishment and development of fungi (MACHADO, 2021). Cover crops and crop rotation could also improve the organic matter content of soils, that is important to the establishment of the biological agent.

In soybean fields, bionematicides are used essentially as seed treatment and few options to in furrow applications are available (AGROFIT 2021). However, Silva et al. (2020) emphasized that the seed treatment with bionematicides as the only tool to manage nematodes in soybean fields does not provide the necessary protection against the damages caused by nematodes, mainly when soil nematode populations are high. On the other hand, under field conditions, when fungi agents were applied in furrow in the cover crops succeeding soybean for the management of $P$. brachyurus, yields increased $180 \mathrm{~kg}$ per hectare in comparison with plots that received only the cover crop treatment (SILVA et al. 2020). The organic matter delivered by the cover crops also favor the development of microorganisms that can parasitize eggs and even the cyst of 
H. glycines, positively impacting the management of this important nematode in soybean crops. For the management of root-knot nematodes in soybean, fungi are preferred, since the main target of the fungal-based bionematicides is Meloidogyne spp. (AGROFIT 2021). Greenhouse experiments have been showing that these organisms reduce around $60 \%$ of the root-knot nematode populations, in controlled environment; however, under fields conditions, the efficacy of fungi used as seed treatment in soybean is variable (SILVA et al. 2020).

Despite the promising results found for cotton and soybean, the management of nematodes in perennial crops, like coffee, is difficult because plants remain in the field for several years; in tropical and subtropical climates, where temperature is not a limiting factor to the development of nematodes, it is expected to occur high increases in the nematode populations during the crop cycle. Unfortunately, few studies are conducted with other perennial crops and bionematicides except coffee.

In studies conducted under greenhouse conditions, bionematicides were used to manage the most damaging nematode species to coffee plantations in Brazil, M. paranaensis, but none of the evaluated bionematicides were effective in reducing the nematode population, although the application of $P$. lilacinum in furrow allowed better development of plants (ARITA et al. 2020). Under field conditions, cover crops or green manures intercropped with coffee plants could improve the management of nematodes, due to the organic matter and the favorable microclimate for the establishment of biological control agents.

The mixture of biological control agents could also improve the efficacy of the biological control of nematodes in coffee plants. Under greenhouse conditions, Tolardo (2018) observed that the mixture of Bacillus subtilis + B. methylotrophicus + Trichoderma asperellum demonstrated similar efficiency to reduce $M$. exigua population densities than that obtained with the use of resistant cultivars. In a field experiment, effective control of $M$. exigua was also observed by Arpini et al. (2018), when a bionematicide formulated with the mixture of $B$. subtilis and $B$. licheniformis (Quartzo ${ }^{\circ}$ ) was applied at high dosages twice (200 g of the commercial product per hectare per application) at intervals of 60 days. However, it is important to emphasize that $M$. exigua is less ag- gressive to coffee plants than $M$. paranaensis, whose management must include a resistant cultivar allied with other management tools to avoid the damages caused by this nematode. Therefore, studies should also contemplate $M$. incognita and $M$. paranaensis to validate the results obtained for $M$. exigua.

\section{FUTURE PROSPECTS}

Despite the expansion of the bionematicide market in Brazil, few minor crops are contemplated in the development of new products. For instance, we have regional problems with nematode species different from the main targets of bionematicides (Table 1), as M. paranaensis in coffee (OLIVEIRA \& ROSA 2018), $M$. enterolobii in guajava, acerola, and vegetables (CARNEIRO 2003; PINHEIRO 2017), the rice complex of root-knot nematodes, including $M$. graminicola (MATTOS et al. 2017), the yam nematodes P. coffeae and Scutellonema bradys (PINHEIRO et al. 2016), the red-ring coconut nematode Bursaphelenchus cocophilus (WARWICK 2001), or the aerial and bulb nematodes Aphelenchoides spp. and Ditylenchus dipsaci (MEYER et al. 2017; PINHEIRO et al. 2014). All of them are difficult to manage with resistant cultivars or crop rotation and any chemical nematicide is available for the control of these targets (AGROFIT 2021). Bionematicides could be an excellent option for the management of these nematodes, especially in organic farms. Companies should invest some efforts to include these "minor nematode species" as biological targets of the bionematicides, improving yields and fruit quality where other management tools are unavailable or fail.

Besides, from 47 commercial bionematicides recommended for nematode management in Brazil, we have only 11 biological agents, in which Bacillus spp. correspond to $60 \%$ of them (AGROFIT 2021). The difficulty in discovering new chemical molecules and the costs associated with the development of chemical nematicides make this poor explored universe of macro- and microorganisms attractive, especially for small companies (MARRONE 2019). Several microorganisms are reported to be effective against plant parasitic nematodes under in vitro conditions, but only a few of them are successful biocontrol agents, mainly because of the difficulties in laboratory culturing, or to access strains from collections or soils, or due to the low effectiveness in 
nematode control (SIDDIQUI \& MAHMOOD 1996). An alternative is the use of metabolites of these organisms as the active ingredient of bionematicides. However, not all natural biochemicals are regulated as biopesticides; for this to happen, the substance needs to have a non-toxic mode of action to the pest or pathogen, as the resistance inducers. Substances with a toxic mode of action to nematodes are regulated as chemicals (MARRONE 2019).

Some microorganisms have been studied and explored for nematode control worldwide, as Myrothecium verrucaria, a fungus that compose the bionematicide DiTera (Valent BioSciences) and Burkholderia rinojensis, the bacteria from Majestene (Marrone Bio Innovations) (MARRONE 2019). Both bionematicides are not available for Brazilian growers, but these organisms could be collected, isolated, and studied by local companies.

The saprophyte bacteria Pseudomonas spp. are used as active ingredients of biopesticides around the world and some species, as $P$. fluorescens, $P$. aeruginosa, and $P$. protegens have already demonstrated their potential in the nematode control. The mode of action involves the destruction of the egg masses, interferences in the hatching, and the cleavage of the ethylene precursor, which inhibit the production of this hormone that is important in the development of galls in roots infected by Meloidogyne spp. (GLAZER et al. 1985; SEENIVASAN et al. 2012; TAVAKOL-NORABADI et al. 2014).

Bacillus thuringiensis is also a potential organism to be used in the management of nematodes. The Cry proteins, that are pore-forming toxins used as insecticides, produced by this bacterium have been demonstrated their potential to reduce nematode populations, especially those isolates that produce low molecular weight proteins that are ingested by nematodes and cause collapse of the digestive system (KHAN et al. 2021).

In Brazil, Duddingtonia flagrans demonstrated a potential to reduce more than $70 \%$ of the number of $M$. javanica juveniles in tomato plants (MONTEIRO et al. 2020). This is a predacious fungus that form adhesive-network traps to capture nematodes with application in the control of helminthic zoonoses (JOBIM et al. 2008). Waitea circinata also demonstrates potential in the control of $M$. javanica in tomato (MENDES, 2021). This species, an orchid mycorrhizal fungus, is known by its high production of secondary metabolites, as alkaloids and steroids, which can be toxic to nematodes (CARVALHO et al. 2015).

In addition to the search for new biological control agents, long-term field studies must be conducted to demonstrate the correct interval for application of bionematicides, considering the wide discrepancies found in climates, soil types, and crop systems between different Brazilian agricultural areas. Besides, there is no concise and reliable information on the effect of mixtures of different microorganisms, whether in the same bionematicide or in different products applied together or in rotation. After several years of research with bionematicides, results from the IDR's Nematology laboratory led to believe that not necessarily bionematicides that have more than one organism in their composition are better than those that contain only one in their formulation. It could be explained by the proper isolate used as active ingredient, which can be more aggressive against the nematode itself, or more agile in colonization of the substrate or root surface as a saprophyte or endophyte gaining an adaptive advantage, or even producing more toxic substances in its secondary metabolism that allow it to have a higher nematicide effect.

Considering the Brazilian biodiversity richness, this universe of new macro- and microorganisms can be explored for the development of new bionematicides. Expectations of an increase in this market are optimistic and can attract small companies, startups, and large investors to supply this increasing biological control market in Brazil.

\section{REFERENCES}

AGROFIT (2021). Produtos técnicos. Available at: http://agrofit.agricultura.gov.br/agrofit_cons/ principal_agrofit_cons. Accessed on April 25, 2021.

AHMED S, MONJIL M (2019). Effect of Paecilomyces lilacinus on tomato plants and the management of root-knot nematodes. Journal of Bangladesh Agricultural University 17: 9-13.

ARITA LY, SILVA SA, MACHADO ACZ (2020). Efficacy of chemical and biological nematicides in the management of Meloidogyne paranaensis in Coffea arabica. Crop Protection 131: 105099. (https://doi.org/10.1016/j.cropro.2020.105099). ARPINI BS, LIMA IM, COSTA NS (2018). Contro- 
le de Meloidogyne exigua em cafeeiro arabica com uso de bionematicida constituído por Bacillus subtilis e B. licheniformis. Available at: https://biblioteca.incaper.es.gov.br/digital/bitstr eam/123456789/3556/1/1006-1180-01.pdf. Accessed on 05 Oct 2021.

BULLOCK J (2019). Formulating biologicals: encapsulation and stability. Agropages 2019 - Biologicals Special, p. 22-23. Available at: http://www. agropages.com/magazine/detail-234.htm. Accessed on May 05, 2021.

CAMPOS F (2020). Produtos biológicos para soja movimentaram US\$ 200 milhões. Revista Cultivar Grandes Culturas. Available at: htpps://www. grupocultivar.com.br/produtos-biologicos-para-soja-movimentaram-us-200-milhoes. Accessed on 05 May 2021.

CARNEIRO RMDG (2003). Uma visão mundial sobre a ocorrência e patogenicidade de Meloidogyne mayaguensis em goiabeira e outras culturas. Nematologia Brasileira 27: 229-230.

CARVALHO JCB, SOUSA KCI, BRITO DC, CHAIBUB AA, LUZINI AP, CÔRTES MVCB, FILIPPI MCCF, VAZ BG, COSTA HB, ROMÃO W, ARAÚJO LG (2015). Biocontrol potential of Waitea circina$t a$, an orchid mycorrhizal fungus, against the rice blast fungus. Tropical Plant Pathology 40: 151-159. (https://doi.org/ 10.1007/s40858-0150042-8).

CHOUDHARY DK, JOHRI BN (2009). Interactions of Bacillus spp. and plants with special reference to induced systemic resistance (ISR). Microbiological Research 164: 493-513. (https://doi.org/ 10.1016/j.micres.2008.08.007).

DALLEMOLE-GIARETTA R, FREITAS LG, CAIXETA LB, XAVIER DM, FERRAZ S, FABRY CFS (2011). Produção de clamidósporos de Pochonia chlamydosporia em diferentes substratos. Ciência e Agrotecnologia 35:314-321.

DALLEMOLE-GIARETTA R, FREITAS LG, LOPES EA, PEREIRA OI, ZOOCA RJF, FERRAZ S (2012). Screening of Pochonia chlamydosporia Brazilian isolates as biocontrol agents of Meloidogyne javanica. Journal of Crop protection 42: 102-107.

DAVIES KG, KERRY BR, FLYNN CA (1988). Observations on the pathogenicity of Pasteuria penetrans, a parasite of root-knot nematodes. Annals of Applied Biology 112: 1491-1501. (https://doi. org/10.1111/j.1744-7348.1988.tb02086.x).
DAVIES KG, ROWE J, MANZANILLA-LÓPEZ R, OPPERMAN CH (2011). Reevaluation of the life-cycle of the nematode-parasitic bacterium Pasteuria penetrans in root-knot nematodes, Meloidogyne spp. Nematology 13: 825-835. (HTTPS://DOI. ORG/10.1163/138855410X552670).

DIAS A (2020). Bond between soybean and biological products, nematicides grows in Brazil. Agropages 2020 - Latin America Focus. Available at: http://www.agropages.com/magazine/detail-254.htm. Accessed on 05 May, 2021.

DINARDO-MIRANDA LL (2014). Nematoides e pragas da cana-de-açúcar. Campinas: Instituto Agronômico.

ESCUDERO N, FERREIRA SR, LOPEZ-MOYA F, NARANJO-ORTIZ MA, MARIN-ORTIZ AI, THORNTON CR, LOPEZ-LLORCA LV (2016). Chitosan enhances parasitism of Meloidogyne javanica eggs by the nematophagous fungus Pochonia chlamydosporia. Fungal Biology 120: 572-585. (https:// doi.org/ 10.1016/j.funbio.2015.12.005).

FARIA JUNIOR P (2017). Biocontrol in Brazil: opportunities and challenges. Agropages 2017 - Biopesticide Supplement. Available at: http://www. agropages.com/magazine/detail-179.htm. Accessed on May 05, 2021.

FERRAZ LCCB, BROWN DJF (2016). Nematologia de plantas: fundamentos e importância. Manaus: Norma Editora.

FRAGA A (2021). Defesa sustentável. Revista Globo Rural, edição maio 2021, p. 60-61.

GAZZONI DL (2021). Bioinsumos na agropecuária. Revista Cultivar Grandes Culturas 264: 44.

GHAHREMANI Z, ESCUDERO N, SAUS E, GABALDÓN T, SORRIBAS FJ (2019). Pochonia chlamydosporia induces plant-dependent systemic resistance to Meloidogyne incognita. Frontiers in Plant Science 10: 1-8. (https://doi.org/10.3389/ fpls.2019.00945).

GLAZER I, APELBAUM A, ORION D (1985). Effect of inhibitors and stimulators of ethylene production on gall development in Meloidogyne javanica infected tomato roots. Journal of Nematology 17: 145-149.

HASHEM A, TABASSUM B, ABD-ALLAH EF (2019). Bacillus subtilis: a plant-growth promoting rhizobacterium that also impacts biotic stress. Saudi Journal of Biological Sciences 26: 1291-1297. (https://doi.org/10.1016/j.sjbs.2019.05.004). 
HU HJ, CHEN YL, WANG YF, TANG YY, CHEN SL, YAN SZ (2017). Endophytic Bacillus cereus effectively controls Meloidogyne incognita on tomato plants through rapid rhizosphere occupation and repellent action. Plant Disease 101: 448-455. (https:// doi.org/10.1094/PDIS-06-16-0871-RE).

IBGE (2017). Senso agro 2017. Available at: censos. ibge.gov.br/agro/2017/. Accessed on 07 June, 2021.

JOBIM MB, SANTURIO JM, DE LA RUE ML (2008). Duddingtonia flagrans: controle biológico de nematoides de bovinos a campo. Ciência Rural 38: 2256-2263.

KAVITHA PG, JONATHAN EI, NAKKEERAN S (2012). Effects of crude antibiotic of Bacillus subtilis on hatching of eggs and mortality of juveniles of Meloidogyne incognita. Nematologia Mediterranea 40: 203-206.

KHAN A, WILLIAMS KL, NEVALAINEN HKM (2006). Infection of plant-parasitic nematodes by Paecilomyces lilacinus and Monacrosporium lysipagum. Biocontrol 51: 659-678. (https://doi. org/10.1007/s10526-005-4242-x).

KHAN TW, DUCK NB, MCCARVILLE MT, SCHOUTEN LC, SCHWERI K, ZAITSEVA J, DAUM J (2021). A Bacillus thuringiensis Cry protein controls Soybean cyst nematode in transgenic soybean plants. Nature Communications 12: 3380. (https://doi. org/10.1038/s41467-021-23743-3).

KERRY BR, KIRKWOOD IA, DE LEIJ FAAM, BARBA J, LEIJDENS MB, BROOKES PC (1993). Growth and survival of Verticillium chlamydosporium Goddard, a parasite of nematodes in soil. Biocontrol Science and Technology 3: 355-365. (https://doi. org/10.1080/09583159309355290).

LEONETTI P, COSTANZA A, ZONNO M, MOLINARI $S$, ALTOMARE C (2014). How fungi interact with nematode to activate the plant defence response to tomato plants. Communications in Agricultural and Applied Biological Sciences 79: 357-362.

MACIÁ-VICENTE JG, ROSSO LC, CIANCIO A, JANSSON HB, LOPEZ-LLORCA LV (2009). Colonisation of barley roots by endophytic Fusarium equiseti and Pochonia chlamydosporia: effects on plant growth and disease. Annals of Applied Biology 155: 391-401. (https://doi.org/10.1111/j.17447348.2009.00352.x).

MACHADO ACZ (2014). Current nematology threats to Brazilian agriculture. Current Agricultural Sci- ence and Technology 20: 26-35. (https://doi. org/10.18539/CAST.V20I1.3737).

MACHADO ACZ (2016). Controle químico. In: Galbieri R, Belot JL (Eds.) Nematoides fitoparasitas do algodoeiro nos cerrados brasileiros: Biologia e medidas de controle. Instituto Mato-grossense do Algodão - IMAmt, Cuiabá. pp. 313-339.

MACHADO ACZ, KANEKO L, PINTO ZV (2016). Controle Biológico. In: Galbieri R, Belot JL (Eds.) Nematoides fitoparasitas do algodoeiro nos cerrados brasileiros: Biologia e medidas de controle. Instituto Mato-grossense do Algodão - IMAmt, Cuiabá. pp. 287-312.

MACHADO ACZ (2021). Problems and solutions to integrated nematode management of root-knot, reniform and lesion nematodes in cotton in Brazil. In: Sikora RA, Desaeger J, Molendijk L (eds.). Integrated nematode management: State-of-theart and visions for the future. CAB International, pp. 73-79. (https://www.cabi.org/cabebooks/ FullTextPDF/2021/20210466450.pdf).

MANZANILLA-LÓPEZ RH, ESTEVES I, FINETTI-SIALER MM, HIRSCH PR, WARD E, DEVONSHIRE J, HIDALGO-DÍAZ L (2013). Pochonia chlamydosporia: advances and challenges to improve its performance as a biological control agent of sedentary endo-parasitic nematodes. Journal of Nematology 45: 1-7.

MARTÍNEZ-MEDINA A, FERNÁNDEZ I, LOK GB, POZO MJ, PIETERSE CM, VAN WEES SC (2017). Shifting from priming of salicylic acid-to jasmonic acid-regulated defences by Trichoderma protects tomato against the root-knot nematode Meloidogyne incognita. New Phytologist 213: 1363-1377. (https://doi.org/10.1111/nph.14251).

MARRONE PG (2019). Pesticidal natural products - status and future potential. Pest Management Science 75: 2325-2340. (https://doi.org/10.1002/ ps.5433).

MASSOLA JÚNIOR NS (2018). Fungos Fitopatogênicos. In: Amorim L, Rezende JAM, Bergamin Filho, A (Eds.) Manual de Fitopatologia Vol.1 Princípios e Conceitos. 5a edição. São Paulo: Agronômica Ceres. pp. 107-141.

MATHEW R, OPPERMAN CH (2020). Current insights into migratory endoparasitism: deciphering the biology, parasitism mechanisms, and management strategies of key migratory endoparasitic nematodes. Plants 9: 671. (https:// 
doi.org/10.3390/plants9060671).

Mattos VS, Soares MRC, Gomes ACMM, Dias-Arieira CR, Gomes, CB, Carneiro RMDG (2017). Caracterização de um complexo de espécies do nematoide das galhas parasitando arroz irrigado na região Sul do Brasil. Boletim de Pesquisa e Desenvolvimento, 331, Embrapa Recursos Genéticos e Biotecnologia, $28 \mathrm{p}$.

MAUCHLINE TH, KERRY BR, HIRSCH PR (2002). Quantification in soil and the rhizosphere of the nematophagous fungus Verticillium chlamydosporium by competitive PCR and comparison with selective planting. Applied and Environmental Microbiology 68: 1846-1853. (https://doi. org/10.1128/AEM.68.4.1846-1853.2002).

MCKENNEY PT, DRIKS A, EICHENBERGER $P$ (2013). The Bacillus subtilis endospore: assembly and functions of the multilayered coat. Nature Reviews Microbiology 11:33-44. (https://doi. org/10.1038/nrmicro2921).

MEDEIROS HA, ARAÚJO FILHO JV, FREITAS LG, CASTILLO P, RUBIO MB, HERMOSA R, MONTE E (2017). Tomato progeny inherit resistance to the nematode Meloidogyne javanica linked to plant growth induced by the biocontrol fungus Trichoderma atroviridae. Nature Scientific Reports 7: 40216. (https://doi.org/10.1038/srep40216).

MENDES BL (2018). Biocontrole de Meloidogyne javanica por fungo micorrízico orquidóide (Waitea circinata) em tomateiro. MsC Dissertation, Universidade Federal de Goiás, Goiânia, GO, Brasil.

MEYER MC, FAVORETO L, KLEPKER D, MARCELINO-GUIMARÃES FC (2017). Soybean green stem and foliar retention syndrome caused by Aphelenchoides besseyi. Tropical Plant Pathology 42:403-409. (https://doi.org/ 10.1007/s40858017-0167-z).

MONTEIRO TSA, BALBINO HM, MELLO INK, COUTINHO RR, ARAÚJO JV, FREITAS LG (2020). Duddingtonia flagrans preying a plant parasitic nematode. Brazilian Journal of Biology 80:197-198. (https://doi.org/10.1590/1519-6984.209748).

MORTON OC, HIRSCH PR, KERRY BR (2004). Infection of plant-parasitic nematodes by nematophagous fungi - a review of the application of molecular biology to understand infection process and to improve biological control. Nematology 6: 161-170. (https://doi. org/10.1163/1568541041218004).
OLIVEIRA CMG, ROSA JMO (2018). Nematoides parasitos do cafeeiro. Boletim Técnico Instituto Biológico n. 32.

ORR JN, NEILSON R, FREITAG TE, ROBERTS DM, DAVIES KG, BLOK VC, COCK PJA (2020). Parallel microbial ecology of Pasteuria and nematode species in Scottish soils. Frontiers in Plant Science 10: 1763. (https://doi.org/10.3389/ fpls.2019.01763).

PASCHOLATI SF, SOUZA VHM, CARDOSO FILHO JA (2019). Indução de resistência por Trichoderma. In: Meyer MC, Mazaro SM, Silva JC (Eds.). Trichoderma: Uso na Agricultura. Brasília, DF: Embrapa.

PIETERSE CMJ, LEON-REYES A, VAN DER ENT $S$, VAN WEES SCM (2009). Networking by small-molecule hormones in plant immunity. $\mathrm{Na}$ ture Chemical Biology 5: 308-316. (https://doi. org/10.1038/nchembio.164).

PINHEIRO JB, CARVALHO ADF, PEREIRA RB, RODRIGUES CS (2014). Nematoides na cultura do alho e cebola. Circular Técnica, 130, Embrapa Hortaliças, $8 \mathrm{p}$.

PINHEIRO JB, PEREIRA RB, MADEIRA NR (2016). Manejo de nematoides na cultura do inhame-cará (Dioscorea sp.). Circular Técnica, 150, Embrapa Hortaliças, $13 \mathrm{p}$.

PINHEIRO JB (2017). Nematoides em hortaliças. Brasília, DF: Embrapa, 194 p.

PODESTÁ GS, AMORA DX, MAFFIA LA, NASU EGC, FERRAZ $S$, FREITAS LG (2016). Effect of time between soil infestation with Pochonia chlamydosporia and planting on the efficacy of the fungus in managing Meloidogyne javanica. Crop Protection 90: 77-83. (https://doi.org/10.1016/j.cropro.2016.08.029).

PRESTON JF, DICKSON DW, MARUNIAK JE, NONG G, BRITO JA, SCHMIDT LM, GIBLIN-DAVIS RM (2003). Pasteuria spp.: systematics and phylogeny of these bacterial parasites of phytopathogenic nematodes. Journal of Nematology 35: 198207.

SANTOS ML, BERLITZ DL, WIEST SLF, SCHÜNEMANN R, KNAAK N (2018). Benefits associated with the interactions of endophytic bacteria and plants. Brazilian Archives of Biology and Technology 61: e18160431. (https://doi. org/10.1590/1678-4324-2018160431).

SEENIVASAN N, DAVID PMM, VIVEKANANDAN P, SAMIYAPPAN R (2012). Biological control of rice 
root-knot nematode, Meloidogyne graminicola through mixture of Pseudomonas fluorescens strains. Biocontrol Science and Technology 22: 611-632. (https://doi.org/10.1080/09583157.20 12.675052).

SIDDIQUI ZA, MAHMOOD I (1996). Biological control of plant parasitic nematodes by fungi: a review. Bioresource Technology 58: 229-239.

SILVA RA, MACHADO ACZ, SANTOS TFS, SILVA RG (2020). Nematoides no sistema de produção. Boletim de Pesquisa Fundação MT.

SKRABANIA K (2019). Improving the performance of microbial agrosolutions: enhanced shelf life and optimized delivery. Agropages 2019 - Biologicals Special, p. 24-25. Available at: http://www. agropages.com/magazine/detail-234.htm. Accessed on May 05, 2021.

STIRLING GR (1984). Biological control of Meloidogyne javanica with Bacillus penetrans. Phytopathology 74: 55-60.

TAVAKOL-NORABADI MT, SAHEBANI N, ETEBARIAN HR (2014). Biological control of root-knot nematode (Meloidogyne javanica) disease by
Pseudomonas fluorescens (Chao). Archives of Phytopathology and Plant Protection 47: 615621. (https://doi.org/10.1080/03235408.2013.8 16102).

TOLARDO, AL (2018). Controle biológico e genético de Meloidogyne exigua em duas cultivares de café. MsC Dissertation, Instituto Federal Goiano, Urutaí, GO, Brasil.

VARGAS WA, MANDAWE JC, KENERLEY CM (2009). Plant-derived sucrose is a key element in the symbiotic association between Trichoderma virens and maize plants. Plant Physiology 151: 792-808.

ZHANG J, CHEN GY, LI XZ, HU M, WANG BY, RUAN $B H, Z H O U H, Z H A O L X$, DING ZT, YANG YB (2017). Phytotoxic, antibacterial, and antioxidant activities of mycotoxins and other metabolites from Trichoderma sp. National Product Research 31:2745-2752. (https://doi.org/10.1080/147864 19.2017.1295235).

WARWICK DRN (2001). Principais doenças do coqueiro (Cocos nucifera L.) no Brasil. Documentos, 22, Embrapa Tabuleiros Costeiros, 33 p. 